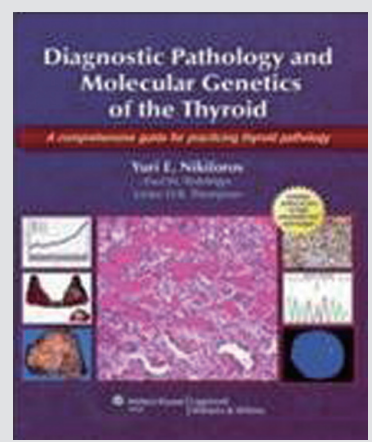

\title{
Diagnostic Surgical Pathology and Molecular Genetics of the Thyroid
}

Yuri Nikiforov, Lester Thompson and Paul Biddinger

Yuri E. Nikiforov가 2009년에 출간한 Diagnostic Surgical Pathology and Molecular Genetics of the Thyroid란 책을 소개하고자 한다. 최근 들어 급증한 갑상선암의 발생률과 더불어 이비인후과의사에게 갑상선암의 진단과 치료과정이 차지하는 중요성은 다시 언급할 필요가 없을 것이다.

Yuri E. Nikiforov은 University of Pittsburgh Medical Center의 Department of Pathology내 Division of Molecular Anatomic Pathology의 director로서 갑상선암 연구, 특히 분자생물학적인 측면에서의 연구에 관심이 있는 의사들에게는 널리 알려져 있는 유명한 병리학자겸 연구자이다. Yuri E. Nikiforov는 단순히 갑상선암종의 형태학적인 병리에만 관심이 있 는 것이 아니라 임상의사들처럼 그 발암기전과 각 유전자변이의 차이에 따른 갑상선암종의 임상양상의 차이, 그리고 진행성 혹은 분화가 나쁜 갑상선암종에 대한 새로운 치료법 등에 관심을 갖고 약 80여 편의 논문을 보고한 바 있다.

1990년대 이후로 여러 갑상선병리에 관한 교과서들이 출간되었으나 최근 들어 갑상선병리에 있어서의 병리학적 진단기준이 새로이 정립되었고 새로운 면역화학염색과 유전자변이들이 출현함에 따라 이러한 급속한 변화를 반영하는 갑상선질환에 대 한 새로운 병리학 교과서가 절실히 필요하게 되었다.

또한 최근 들어 분자생물학적인 개념이 갑상선암 연구를 비롯한 모든 의학의 분야에 영향을 미치고 있는 시점에 Yuri E. Nikiforov가 저술한 이 책은 이비인후과의사에게도 단순히 갑상선질환의 진단을 위한 병리보다는 고식적이고 형태학적인 병 리와 그러한 병리에 대한 기전을 분자생물학적으로 설명해주는 교과서라 할 수 있다. 이 책에서는 각 질환의 현재 발생률, epidemiology, 각 갑상선암종의 발암기전을 각각의 병리학적인 차이(면역화학염색, gross \& microscopic 소견, 전자현미경소 견, 세침흡인 세포검사, 다양한 감별진단)와 함께 자세히 기술한 점, 자세한 임상양상과 영상의학적인 특징의 기술 등이 일 관되게 기술된 점이 돋보인다.

특히 본 책의 마지막 장에서는 갑상선암종의 발암기전에 관여하는 여러 유전자변이에 대한 연구를 시작하고자 하는 연구 지들을 위한 분자생물학적 진단법에 대한 자세한 설명을 다루었다.

이 책을 통하여 최근 이비인후과의사에게도 이슈가 되고 있는 갑상선암종의 병리학적인 개념에 대한 이해뿐 아니라 발암 기전에 대한 이해 그리고 나아가 갑상선암종에 대한 기초연구에 도움이 될 것이라 생각한다.

대한이비인후과학회 간행위원회 